\title{
KILAS BALIK KHITAH NU DALAM KONTEKS POLITIK LOKAL DI JOMBANG
}

\author{
Sukamto \\ Fakultas Syariah IAIN Sunan Ampel Surabaya
}

\begin{abstract}
Abstrak; Membahas tentang elite NU dalam konteks politik lokal di Jombang, tulisan ini mengawalinya dengan peristiwa muktamar NU 1984 di Situbondo, yang menghasilkan konsep khitah NU 1926. Muktamar NU itu mempunyai pengaruh lebih lanjut dengan timbulnya peristiwa politik di tingkat lokal Jombang. Peran elite politik lokal menjadi sumber lahirnya dinamika politik di tingkat lokal. Dikatakan politik lokal karena aktivitas politiknya terjadi di daerah, dan untuk bahasan ini mengambil sampel di wilayah Jombang. Para pelaku politik lokal, biasanya tinggal di daerah atau mempunyai akses kekuasaan dengan daerah tersebut yang terdiri atas tokoh masyarakat dan agama yang memimpin pondok pesantren, organisasi sosial keagamaan dan tarekat. Mereka mempunyai pengaruh di masyarakat dan terlibat dalam kegiatan politik di daerah Jombang. Elite NU di Jombang didominasi oleh pimpinan pesantren dan komunitas santri, serta tokoh agama yang mengambil peran di organisasi NU. Kajian ini bermaksud mencermati pengaruh hasil muktamar Situbondo dalam konteks politik lokal, dimana elite politik NU Jombang memiliki perbedaan pandangan dalam mengartikan kebijakan khitah NU. Dampak dari persepsi yang berbeda ini melahirkan sikap dan perilaku politik yang berbeda diantara para elite politik yang duduk di kepengurusan NU Jombang. Sebagian besar elite $\mathrm{NU}$ berasal dari kalangan pimpinan pesantren dan tarekat, maka perbedaan itu juga lebih lanjut mempengaruhi hubungan antar elite-elite di pesantren. Politik NU pasca muktamar Situbondo menyisakan banyak pekerjaan bagi warga NU dan pesantren di daerah Jombang, paling tidak implementasinya menimbulkan sikap pro dan kontra, yang akhirnya terjadi friksi di tubuh NU Jombang dan renggangnya hubungan antar elite pesantren atau tarekat.
\end{abstract}

Kata Kunci : Elit NU, Khittah, Politik Lokal 


\section{Pendahuluan}

Sebagai organisasi terbesar di Indonesia, keputusankeputusan politik NU sering menjadi barometer dari pergerakan Islam di Indonesia, tidak jarang sikap politik NU menjadi rujukan organisasi sosial maupun organisasi politik, baik keputusannya bersifat kooperatif berupa dukungan atau bersifat non kooperatif yang terkesan berseberangan. Ketika muktamar di Situbondo menghasilkan keputusan bahwa NU menerima Pancasila sebagai satu-satunya asas dalam menata kehidupan berbangsa, yang mana keputusan tersebut merupakan momentum penting untuk menepis anggapan bahwa keberadaan Pancasila masih diperdebatan bagi ketatanegaraan di Indonesia ${ }^{1}$. Namun dengan keputusan itu telah memperkuat legitimasi Pancasila sebagai dasar bagi kehidupan berbangsa dan bernegara serta bersifat final, yang berarti siapapun yang mempersoalkan Pancasila, bakal berhadapan dengan warga NU. Tentu pihak pemerintah merasa senang dengan keputusan NU seperti itu, sebagai organisasi terbesar pengaruhnya di Indonesia yang berani menjadi bemper dalam menyeragamkan asas-asas organisasi sosial maupun politik. Langkah yang demikian tidak lepas dari kritikan-kritikan pihak lain, yang merasa kecewa dengan sikap NU seperti itu. Meski demikian, keputusan NU itu diikuti oleh organisasi-organisasi sosial yang lainnya.

Kembalinya NU ke khitah telah merubah konstelasi politik PPP, baik yang berhubungan dengan unsur-unsur partai yang tergabung dalam fungsi PPP maupun dikaitkan dengan peranan NU dalam kehidupan sosial lebih besar. Merosotnya perolehan PPP pasca khitah NU menjadi indikasi kuat bahwa peran politik NU di PPP sangat besar. Jika saja unsur partai NU merasa tidak terpinggirkan dalam PPP karena kebijakan pimpinan PPP yang merugikan politisi NU dari pesantren, tentu persoalan ini tidak akan membawa NU ke jalan firqah. Sebagaimana, yang

Lihat, Feillard, Andree, Nahdhatul Ulama dan Negara; Fleksibelitas, Legitimasi dan Pembaharuan, dalam Gus Dur, NU dan Masyarakat Sipil, (Ellyasa KH Darwis), h. 25-26

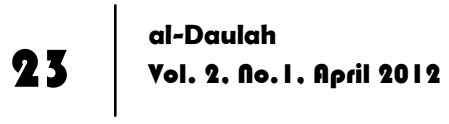


diungkapkan oleh Kiai Yusuf Hasyim bahwa orang-orang NU tetap berat dengan PPP, namun J. Naro, selaku pimpinan PPP membuat kebijakan partai yang dipandang merugikan NU, maka warga NU mengambil sikap tegas.

Peranan NU di masyarakat selalu dikaitkan dengan upaya mengembangkan fungsi sosial NU dalam kehidupan sosial politik yang kontekstual. Artinya bahwa organisasi NU mempunyai bidang garapan yang langsung dengan kehidupan masyarakat. Mayoritas warga NU sendiri bertempat tinggal di perdesaan, yang tingkat kehidupan sosial ekonominya masih jauh tertinggal. Dengan keputusan NU kembali ke khitah, meski berdampak negatif pada PPP, tetapi elite NU menyadari bahwa problem ekonomi warga NU belum mendapatkan perhatian dari organisasi NU sendiri ${ }^{2}$. Berbicara tentang elite NU Jombang sama artinya dengan berbicara tentang kiai-kiai pondok pesantren. Setiap pimpinan NU cabang Jombang hampir semuanya pernah berasal dari pondok pesantren atau memiliki hubungan keluarga dengan anggota keluarga pondok pesantren. Jabatan NU Jombang terbuka luas bagi para kiai dan santri-santri dari pondok pesantren. Jika kandidat pimpinan cabang NU Jombang lebih dari seorang kiai, maka yang terpilih adalah kiai yang memiliki hubungan dekat dengan pesantren pendiri NU. Kendati, peran elite pesantren/NU menjadi sumber dinamika politik lokal, namun, imbas politiknya tak terbatas pada lingkungan sosial sekitar Jombang. Elite politik lokal juga melibatkan kroni-kroni elite politik di tingkat pusat, dalam memperkuat orientasi politik yang menjadi pilihannya ${ }^{3}$.

Kajian ini meliputi antara lain peranan kiai-kiai pesantren dalam menyikapi aspek sosial politik yang sedang berkembang di Indonesia. Kiprah politik kiai memang diakui cukup besar, terutama dari empat pimpinan pesantren besar di Jombang, yang

${ }^{2}$ Lihat, Muhammad AS Hikam, Khitah dan Penguatan Civil Society di Indonesia; Sebuah Kajian Historis dan Struktural atas NU sejak tahun 1984, dalam Gus Dur, NU dan Masyarakat Sipil, Op., Cit., h. 133-164

${ }^{3}$ Endang Turmudi, Perselingkuhan Kiai Dan Kekuasaan, Yogjakarta, LkiS, 2004, h., 152 
hampir semua kiainya pernah terlibat dukung mendukung partai politik. Keikutsertaan mereka berpolitik telah mempengaruhi sikap dan perilaku politik santri, sehingga orientasi politik kiai menjadi rujukan santri. Dalam realitas sosial, para kiai yang terjun di partai politik selalu mempertimbangkan aspek untung dan ruginya, apakah bermanfaat atau tidak terhadap lembaga pesantren yang dipimpinnya. Jika kemaslahatan untuk pesantrennya lebih besar, maka mereka akan terjun berpolitik dan jika tidak, maka mereka akan mengurungkan niatnya. Memasuki partai politik berkaitan dengan cita-citanya membangun pondok pesantren, yang diharapkan dapat meningkatkan pembangunan fisik gedung-gedung pesantren dan kualitas pendidikan di pesantren ${ }^{4}$.

\section{Kronologis dan Gagasan Ke Khitah}

Gagasan NU ke khitah 1926, dengan tekad memurnikan kembali visi dan missi NU dalam konteks perjuangan sosial keagamaan umat ${ }^{5}$ dan tidak melulu bidang politik, sebenarnya telah muncul tahun 1959, 3 tahun pasca pemilu tahun 1955. Dalam penyelenggaraan muktamar NU ke 22 di Jakarta, tanggal 13-18 Desember 1959, gagasan kembali ke khitah disampaikan Kiai Achyat Chalimi, ${ }^{6}$ selaku utusan dari Cabang NU Mojokerto. Ia antara lain mengatakan bahwa selama ini peranan NU dalam partai politik telah meninggalkan prinsip utamanya sebagai organisasi diniyah, NU sendiri dijadikan sebagai alat politik oleh orang-orang atau kelompok tertentu yang hanya untuk memenuhi kepentingan pribadinya. Realita seperti ini membuat NU sebagai partai politik, sesungguhnya NU telah kehilangan peran

${ }^{4}$ Wawancara dengan Shobirin, 19 Agustus 2005, dan bahkan bukan menjadi rahasia lagi bahwa masuknya kiai-kiai di pesantren Jombang lebih didasarkan pada pertimbangan dalam mengangkat citra dan kualitas unit pendidikan di pesantren

${ }^{5}$ Lihat, Einar M. Sitompul, NU, Asas Tunggal Pancasila dan Komitmen Kebangsaan; Refleksi Kiprah NU Pasca Kitah 26., dalam Gus Durn NU dan Masyarakat Sipil (Ellyasa KH. Darwis, editor)., LkiS, Yogjarakat., h., 87-89

${ }^{6}$ Kacung Marijan, Quo Vadis NU Setelah Kembali ke Khitah 1926, Surabaya, Penerbit Erlangga, 1992, h. 132 
politiknya. Usulan ini disampaikan setelah melihat kenyataan di lapangan bahwa orang-orang NU yang berkarier di partai politik tidak memberikan konstribusi dalam mengangkat citra NU. Sebagai partai politik, elite partai NU seharusnya mampu menyerap aspirasi dari kalangan ulama di pesantren. Usulan itu tidak mendapatkan respon positif, malah sebaliknya peserta muktamar mempertanyakan tentang motivasi dibalik gagasan itu. Gagasan itu sebagai hal yang mustahil diterima karena NU justru mengambil langkah mafarraqah dengan Masyumi atas dasar keinginan mendirikan partai politik sendiri, mengapa tiba-tiba muncul usulan meninggalkan gelanggang politik. Latar belakang perpisahan NU dengan Masyumi merupakan kekecawaan para elite NU yang rata-rata dari pesantren, karena kedudukan NU dalam partai tersebut terancam oleh politisi Islam yang berhaluan modernis.

Sebagian besar penentang gagasan tersebut berasal dari para politisi muda NU, yang selalu berhadapan dengan kelompok kiai, yang sehari-harinya bergerak di bidang edukasi pesantren. Kedua kelompok internal NU, yaitu antara politisi dan pengajar, selalu muncul dalam setiap kali membahas konteks sosial NU dalam kehidupan berbangsa, disatu sisi, menghendaki hak politik NU harus diakui dan di sisi lain, menghendaki NU lebih consern terhadap sosial dan agama. Para kiai pesantren mengibaratkan bahwa NU itu dilahirkan dari pesantren, seharusnya sebagai anak (politisi NU) harus menuruti ibu kandungnya (pesantren atau kiai). Begitu NU mengalami perkembangan pesat dan menjadi besar, tiba-tiba diambil oleh orang lain atau kalangan politisi, yang sering kali tidak menghiraukan dan bahkan membantah apa yang difatwakan oleh kiai-kiai pesantren.

Gagasan NU untuk kembali kembali sebagai jam'iyah diniyah muncul lagi pada muktamar NU ke 23 tahun 1963, yang diselenggarkan di Solo, Jawa Tengah, namun gagasan itu tetap tidak mendapatkan respon yang menggembirakan. Sebagian para muktamirin masih menginginkan NU terlibat dalam kancah 
politik. Secara diplomatis, Kiai Idham Chalid, selaku ketua Umum NU membandingkan sambil menyatakan bahwa Masyumi yang dibubarkan oleh pemerintah saja berjuang habis-habisan untuk merebut haknya kembali, agar kembali menjadi partai politik, masak NU yang sudah menjadi partai politik kemudian dikubur oleh komunitasnya sendiri. Meninggalkan politik adalah sesuatu yang tidak mungkin dapat disetujui oleh warga NU. Pernyataan ini disampaikan oleh ketua umum NU dalam menanggapi usulan dari kelompok internal NU yang belum bisa memahami konteks perjuangan sosial politik NU. Dan usulan yang bersifat menggugah peran sosial NU yang tertinggal agar segera diperbaiki dengan langkah kembali ke khitah adalah selalu dipresentasikan oleh komunitas pesantren tetapi tidak mendapatkan apresiasi.

Dalam muktamar NU ke 25, tahun 1971, yang bertempat di Surabaya, para kiai/ulama dari pesantren melontarkan gagasan yang sama seperti pada muktamar-muktamar sebelumnya. Kiai Wahab Chasbullah, selaku Rais 'Aam mendukung gagasan itu, yang disampaikan dalam pidato pembukaan (iftitah) pelaksanaan muktamar. Tetapi para muktamirin tidak menyetujui gagasan itu, karena sebagian besar warga masih menginginkan NU tetap memberikan hak politiknya pada partai politik. Gagasan itu tidak begitu mendapatkan sambutan positif dari peserta, karena bersamaan dengan itu perhatian para muktamirin tertuju pada konflik antara Kiai Idham Chalid dengan HM Subhan ZE. Arena muktamar yang ke 25 lebih banyak memberitakan perseteruan antara Kiai Idham Chalid yang didukung oleh kelompok tua dan berhadapan dengan HM Subhan ZE yang didukung oleh generasi muda NU. Dari kondisi muktamar yang demikian tegang seputar konflik kedua kubu tersebut, akhirnya gagasan mengembalikan NU ke konsep khitah tidak menarik perhatian dan agenda itu hilang begitu saja8 .

${ }^{7}$ Ibid, h. 133

${ }^{8}$ Ibid, h. 133-135 
Setiap kali pelaksanaan muktamar, gagasan NU kembali ke khitah senantiasa muncul tetapi tidak pernah terwujud. Dalam pelaksanaan muktamar ke 26, tanggal 5-11 Juni tahun 1979, yang berlangsung di Semarang juga digulirkan pokok-pokok pikiran agar NU melakukan evaluasi secara detail tentang seberapa jauh keuntungan yang diperoleh dalam kiprah sosialnya warga NU terhadap kehidupan sosial kemasyarakatan. Gagasan ini dilontarkan sebagai bentuk kepedulian NU yang besar pada aspek sosial daripada menekuni masalah politik di bawah bendera PPP. Adalah Kiai Makhrus Ali dari pesantren Lirboyo Kediri yang berani menyampaikan kritik pedas terhadap perilaku komunitas NU yang dianggap telah menyeret eksistensi NU identik dengan partai politik. Ulama-ulama pesantren tidak terlibat dalam politik ikut tetapi merasakan dampak dari sikap politik para politisi NU, adalah sesuatu yang tidak adil dan perlu intropeksi. Di sisi lain, Kiai Mahrus Ali menyampaikan pernyataan bahwa dalam komunitas NU telah terjadi kerusakan moral atau dekadensi moral yang meluas dalam NU, sehingga para politisi NU lebih menyukai kehidupan dunia dengan ambisius terhadap kedudukan dan kekuasaan. Faktor ini yang menjadikan NU sebagai barang rebutan untuk meraih jabatan/kedudukan dan ramainya NU hanya menjelang pelaksanaan pemilu. Karena itu, ia menekankan pada para muktamirin agar segera NU mengembalikan jati diri NU sebagai organisasi keagamaan (jam'iyah diniyah). Tetapi situasi muktamar yang didominasi oleh para politisi tetap menghendaki eksistensi NU di medan politik daripada kelompok penggagas ide tersebut, yang rata-rata berasal dari lembaga pesantren. Dalam muktamar itu, keinginan NU agar kembali ke organisasi diniyah mengalami jalan buntu dan tidak cukup mendapat respon peserta muktamar, gagasan NU kembali ke khitah gagal lagi.

Kiai Hasyim Asy'ari sebagai founding fathers NU, mempunyai pengaruh sangat kuat dalam organisasi NU. Pengaruh itu dirasakan sampai sekarang, dimana orang selalu merujuk sikap 
politik pimpinan pesantren tersebut. Sebagai bukti atas kebesaran Tebuireng, dukungan yang diberikan oleh pimpinan pesantren Tebuireng terhadap PPP sangat besar pengaruhnya dalam meningkatkan suara PPP. Dan sebaliknya, aksi penggembosan yang pernah diprakarsai oleh Kiai Yusuf Hasyim, berdampak atas kemerosotan suara PPP. Pesantren Tebuireng sebagai pusat kultur orang-orang NU harus diakui atas keberhasilannya dalam membesarkan PPP dan sebaliknya, merosotnya suara PPP secara drastis ketika pihak Yusuf Hasyim melakukan aksi penggembosan secara terang-terangan dalam pemilu 19879. Aksi penggembosan sebagai wujud kekecewaan warga NU terhadap pimpinan PPP, sekaligus menjadi indikasi bagi eksistensi NU sendiri di kalangan politisi PPP.

Kiai Yusuf Hasyim dikenal sebagai generasi pewaris NU, mempunyai pengaruh besar dalam pentas politik, terutama saat NU menjadi partai politik atau ketika menjadi unsur terkuat dalam PPP, telah mendidik santri-santri Tebuireng yang akhirnya mengikuti jejaknya masuk partai politik. Sebagian politisi muda $\mathrm{NU}$, yang rata-rata pernah mengenyam pendidikan pesantren di Tebuireng tidak pernah lupa nasehat dan sarannya, agar alumninya tetap membela NU. Rumah kediaman Kiai Yusuf Hasyim sering didatangi kalangan muda yang berasal dari berbagai golongan, yang ingin memperoleh transmisi pengalaman politiknya. Karena itu, saran-saranya tentang masalah politik menjadi rujukan umat dalam menentukan sikap dan perilaku politiknya. Saya pernah bertemu dengan beberapa orang yang sowan kepadanya untuk memberitahukan bahwa dirinya telah dipilih dan diangkat sebagai anggota legislatif, di daerahnya, Kiai

\footnotetext{
${ }^{9}$ Riaty Rafiuddin, Pengaruh Kiai NU Terhadap Kecenderungan Memilih Di Kalangan Santri Dalam Pemilu 1987; Studi Kasus 4 Pondok Pesantren di Jombang Jawa Timur, Skripsi Fakultas IImu Sosial dan IImu Politik Universitas Indonesia, Jakarta, 199, h., 97
} 
Yusuf Hasyim senang mendengarnya dan sambil menceritakan pengalaman politiknya dan strategi dalam berpolitik ${ }^{10}$.

Kiai Yusuf Hasyim, pada tahun 1982, telah memperkirakan dukungan suara PPP bakal mengalami kemerosotan, karena, unsur pimpinan PPP tidak pernah menggubris nasehat dari kiaikiai NU. Bagaimanapun beberapa kiai NU adalah inspirator berdirinya PPP, yang tentu harus diperhatikan kepentingan politiknya. Sementara itu, hubungan antara J Naro dengan Kiai Yusuf Hasim makin hari makin suram dan ditambah lagi dengan kebijakan sewenang-wenangnya dalam mengganti susunan daftar nama calon legislatif yang diusulkan pihak NU. Kiai ini bersama dengan koleganya yang terkena penggusuran pernah menanyakan hal itu tetapi tidak mendapatkan perhatian dan bahkan justru terkesan melecehkan warga NU. Meski demikian, akibat sengketa dengan J Naro, Kiai Yusuf Hasyim tidak langsung melakukan aksi penggembosan. Pengaruh begitu besar, yang ia miliki di masyarakat dapat diketahui dari tingkat kenaikan dukungan santri terhadap PPP pada pemilu 1982, dan tingkat kemerosotannya pada pemilu 1987. Ia bersama-sama dengan tokoh NU lainnya, termasuk dengan Kiai Achmad Siddiq akhirnya membuat sikap terhadap partai politik, Golkar, PDI dan PPP ${ }^{11}$.

Pada tahun 1982, jabatan ketua umum PPP dipegang oleh J. Naro untuk mengganti kedudukan Mintareja, SH. Sebenarnya, pergantian kepemimpinan ini tidak begitu disukai oleh elite $\mathrm{NU}^{12}$. Sosok Kiai Idham Chalid selaku pemegang jabatan presiden PPP yang dijadikan harapan warga NU agar menggunakan wewenangnya dalam membela kepentingan NU, tidak kunjung

\footnotetext{
${ }^{10}$ Muhammad Rofik dari Gresik, seorang alumnus Tebuireng yang sedang menjadi anggota DPRD dari fraksi PPP dan sekarang di PKB, yang datang bersama rombongan sowan ke Kiai Yusuf Hasim, 1992

" Lihat, tulisan William Lidlle yang menyebutnya pimpinan NU dalam sikap politiknya bahwa a vote for PPP is not required, for Golkar not prohibited, for PDI not crime, dalam Indonesia in 1987; The New Order at the height of its Power, dalam Political Science, The Ohio State University, 1988, h., 8

12 Umaidi Radi, Strategi PPP; Suatu Studi Tentang Kekuatan Politik Tingkat Nasional, Jakarta, Integritas Press, 1984., h., 138
} 
tiba. Karena terlambatnya dalam bersikap, maka kiai-kiai pesantren mulai mempertanyakan integritas Kiai Idham Chalid terhadap masa depan NU di PPP. Di sisi lain, terjadi konflik antara pihak NU dengan pihak MI yang diawali dengan tuntutan jatah kursi dari MI begitu besar karena mereka menganggap sebagai pewaris Masyumi (bulan bintang), yang dianggap oleh kalangan NU terlalu berlebihan. Melihat sikap tidak tegas dari Kiai Idham Chalid, maka para ulama senior, yang terdiri atas Kiai As'ad Syamsul Arifin, Kiai Ali Maksum, Kiai Makhrus Ali dan Kiai Ahmad Siddiq, secara bersama-sama mengadakan pertemuan di Surabaya pada awal bulan Mei 1982 untuk mengkritisi kiprah sosial politik NU selama kurun waktu 1977-1982 dalam PPP. Para kiai yang hadir mengambil kesimpulan bahwa perkembangan politik NU di tingkat nasional tidak begitu membawa manfaat bagi kelangsungan organisasi dan warga NU sendiri. Padahal hubungan para kiai dengan pihak pemerintah di tingkat daerah berjalan lancar dan tidak ada kendala yang berarti bagi pesantren ${ }^{13}$.

\section{Kelompok Pro Khitah dan Non Khitah}

Kelompok yang menamakan dirinya sebagai pelopor khitah, sejak semula mendorong terselenggaranya muktamar di Situbondo dengan agenda meloloskan NU dari bingkai politik praktis dalam bendera PPP. Kelompok ini dimotori oleh generasi ulama NU periode ketiga dari sejak berdirinya NU. Generasi pertama NU adalah Kiai Hasyim Asy'ari, Kiai Wahab Chasbullah, Kiai Wahid Hasyim. Kelompok generasi ketiga adalah Kiai Ahmad Siddiq, Kiai Ali Yafie, Kiai Radi Sholeh, Kiai Najib Ridhwan, Kiai Tholhah Mansyur, Kiai Sahal Mahfud dan Kiai Yusuf Hasyim. Generasi ketiga ini mendukung gagasan/prakarsa dari kiai-kiai sepuh/generasi kedua yang menginginkan NU berorientasi pada ide dasar pemikiran NU tahun 1926. Kiai sepuh/generasi kedua

${ }^{13}$ Hilmy Mochtar, Dinamika Nahdhatul Ulama; Suatu Studi Tentang Elite Kekuatan Politik Islam di Jombang Jawa Timur, Tesis S-2 Universitas Gajah Mada, 1987, h. 92

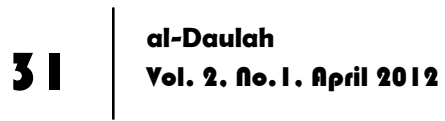


terdiri atas Kiai As'ad Syamsul Arifin dan Kiai Ali Maksum, yang secara langsung pernah menjadi pelaku sejarah perjalanan NU di era generasi pertama.

Berkaitan dengan agenda khitah, antara Kiai As'ad Syamsul Arifin dan Kiai Ali Maksum, melakukan shalat istikharah untuk mintak petunjuk Allah atas terwujudnya kebaikan-kebaikan NU dimasa depan. Dengan istikharah itu, mereka berdua memberikan saran-saran sifatnya spiritual agar mengembalikan NU dalam konteks perjuangan sosial keagamaan, atau ke khitah NU 1926. Generasi NU lapis keempat adalah generasi NU yang akan mengawal langkah NU pasca muktamar NU di Situbondo agar keputusan khitah berlaku dengan baik sampai ke tingkat ranting. Generasi ini terdiri atas generasi muda NU yang diorbitkan sebagai pengganti generasi ketiga, yaitu Abdurrahman Wahid, Syaiful Mujab, Hasyim Latif, Mahbub Junaidi, Ramas Djajasaputra, Fahmi Syaifuddin, Ahmad Bagja, Asnawi Manaf dan Said Buairy ${ }^{14}$.

Selain kelompok pro khitah, muncul kelompok lain dalam tubuh NU, yaitu kelompok non khitah yang merasa tidak puas dengan hasil keputusan muktamar NU Situbondo yang substansinya menjauhkan warga NU dari kepentingan politik praktis, di PPP. Kelompok ini menyampaikan kekecewaannya terhadap sikap sebagian besar ulama-ulama dari pesantren yang dianggap telah mengabaikan begitu saja pentingnya faktor kesejarahan NU berfusi dalam PPP. Kelompok ini menyatakan bahwa sikap ulama yang memahami khitah demikian alergi dengan PPP, dapat dipastikan kepentingan politik NU/hak politik warga NU terabaikan dengan dalih kembali ke kithah. Dasar pemikiran kelompok ini bermaksud menghargai hak-hak politik warga NU sebagai bagian dari hak berwarganegara. Mengembalikan NU pada fungsi organisasi sosial keagamaan adalah sesuatu yang wajar, tetapi jika pengertian khitah diarahkan menarik dukungan dalam barisan PPP berarti NU sendiri telah

${ }^{14}$ Arif Mudatsir, Dari Situbondo Menuju NU Baru, dalam Prisma, Edisi Ekstra, 1984 h. 133 - 139

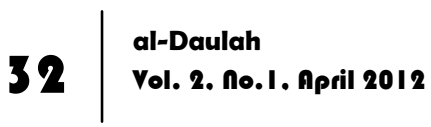


menafikan hak politik warga NU. Dalam kenyataannya dilapangan, implementasi khitah lebih didasarkan pada gerakan massa warga NU untuk keluar atau menjauhi PPP dan membebaskan hak suara warga NU dari keterikatannya dengan PPP. Gerakan ini sangat disayangkan oleh kelompok non khitah, yang menggiring arti khitah hanya sesuai kepentingan pribadipribadi kiai tertentu.

Kelompok non kithah sangat bersikap keras menyerang person-person yang dianggapnya merupakan ganjalan bagi kalangan politis NU. Dengan dalih kembali ke khitah, kelompok yang menamakan khitah ingin sekali meninggalkan PPP. Kelompok non khitah berasumsi bahwa kembali ke khitah NU 1926, tidak harus diartikan warga NU lepas dari ikatan emosional dengan PPP. Keputusan khitah perlu memberikan ruang gerak yang seimbang antara aspek sosial keagamaan dan bidang politik, yang mana kedua bidang ini jelas berbeda. Garapan bidang sosial keagamaan dapat dilakukan secara proporsional tanpa harus menanggalkan kepentingan partai politik. Kelompok non khitah mensinyalir muncul indikasi penafsiran yang berlebihan terhadap konsep khitah atau berkedok alasan khitah, yang arah sasarannya menghilangkan hak-hak politik warga NU dalam barisan PPP. Dengan konsep khitah yang diarahkan keluar dari PPP akan merugikan para politisi NU yang berada di PPP.

Hasil keputusan dari pertemuan itu, akhirnya meminta kepada Kiai Idham Khalid mengundurkan diri dari ketua umum PB NU. Ia dianggap tidak mampu lagi memimpin NU dalam menghadapi dinamika politik yang berkembang saat itu dan tidak memiliki responsibilitas terhadap masalah-masalah mendasar yang timbul di NU. Kiai As'ad Syamsul Arifin kemudian mendatangi rumah Kiai Idham Cholid untuk menyampaikan hasil pertemuan tersebut, sambil menyatakan dengan bahasa lugas bahwa para kiai-kiai memintanya secara hormat mengundurkan diri dari pucuk pimpinan NU. Menanggapi permintaan itu, Kiai Idham Cholid merespon positif, dengan menyampaikan 
pernyataan bahwa ia bersedia mundur dari jabatan ketua PB NU. Pernyataan ini disampaikan sendiri oleh Kiai Idham Chalid. Kelompok pihak Kawatan (perundingan topik pengunduran Kiai Idham ini diprakarsai oleh Kiai As'ad Syamsul Arifin dkk, di kampung Kawatan Surabaya) tidak dapat menyembunyikan rasa gembira kecuali dengan mengucapkan syukur kepada Allah, toh semua pihak saling menyadari dan ini sebagai bukti bahwa pengunduran diri Kiai Idham Cholid demi kepentingan NU yang lebih besar ${ }^{15}$. Hubungan antara Kiai Idham Chalid dan Kiai As'ad Syamsul tetap harmonis, selain mereka saling mengutamakan sikap islah dan uswah. juga sikap tersebut sebagai pertanda bahwa diantara ulama-ulama NU tetap mempertahankan tradisi kepatuhan antara kiai yunior terhadap kiai senior. Ulama-ulama NU berpinsip bahwa berjuang tidak semata-mata mengharap jabatan atau merengguh kekuasaan.

Tetapi sikap pengunduran diri Kiai Idham Khalid ${ }^{16}$ atas permintaan kelompok Kawatan ini berlangsung tidak lama. Surat pengunduran dicabut dan hanya berlaku tidak lebih dari 2 minggu. Kronologis peristiwa pencabutan kembali berjalan cepat setelah sikap pengunduran dirinya menyebar ke berbagai kalangan masyarakat, yang ditanggapi berbeda oleh sebagian kelompok NU sendiri. Dengan munculnya reaksi keras dari sejumlah politisi NU yang diwakili oleh Chalid Mawardi dan Amin Iskandar atas pemaksaan terhadap Kiai Idham Cholid. Atas prakarsa dari 2 politisi ini, sikap Kiai Idham Khalid berubah pikiran dengan tetap mempertahankan jabatan ketua umum sampai masa jabatannya berakhir. Mereka berprinsip bahwa pergantian jabatan adalah hal yang pasti dilalui tetapi tidak dengan cara memaksakan kehendak, telah diatur mekanismenya

15 lihat lebih lanjut dalam Kharisma Kiai As'ad di Mata Umat (Syamsul A. Hasan, editor), LkiS., Yogjakarta, 2003, h., I5- 22

16 Konflik antar Kiai As'ad Syamsul Arifin versus Kiai Idham Chalid, dapat dilihat dalam, Choirul Anam, Pertumbuhan dan Perkembangan Nahdhatul Ulama, Solo, Jatayu, 1985, h, 276-280; Umaidi Radi, Op., Cit, h. 138-145; Slamet Efendi Yusuf, dkk., Dinamika Kaum Santri; Menelusuri Jejak dan Pergolakan Internal NU, Jarakta, Grafiti Press, 1983, h. 72- 105

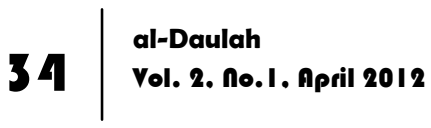


dalam AD/ART NU. Pada saat itu juga Kiai Idham Chalid membuat pernyataan ulang yang berisikan pencabutan atas pernyataan pengunduran diri dari ketua PB NU sebelum pelaksanaan muktamar NU.

Berita yang mengejutkan ini mula-mula hanya tersebar di kalangan elite NU tertentu, tetapi kemudian para politisi NU menginginkan pernyataan ini cepat tersebar dan didengar oleh warga NU, maka disebarluaskan di kalangan anggota DPR, yang akhirnya berita ini sampai pada kelompok Kawatan, yaitu Kiai As'ad Syamsul Arifin dkk. Bersamaan itu pula, kelompok Kiai Idham Chalid merapatkan barisan dalam mempertahankan jabatan dari upaya segelintir ulama yang dianggap sebagai gerakan kudeta, yang diprakarsai kelompok Kawatan. Pihak Kiai Idham Chalid menyebut tindakan itu sebagai tindakan indisipliner organisasi. Kelompok penentang gerakan Kawatan, yang diwakili Chalid Mawardi, menyatakan bahwa mekanisme pengunduran diri telah diatur dalam organisasi NU dan jika dilakukan secara sepihak dan tidak berdasarkan prinsip-prinsip organisatoris adalah jelas-jelas melanggar kode etik NU. Membuat keputusan dengan cara memaksa seseorang turun dari jabatan akan merusak citra NU sendiri, seharusnya para kiai memahami aturan main organisasi NU, apalagi mereka merasa memiliki tanggung jawab terhadap organisasi. Sebagai langkah pengamanan terhadap posisi Kiai Idham Chalid, maka kelompok Chalid Mawardi dkk. menyatakan bahwa suara daerah-daerah yang berjumlah 27 wilayah telah mendukung kepemimpinan Kiai Idham Chalid sebanyak 17 pimpinan wilayah ${ }^{17}$.

Dari peristiwa itu, di satu sisi, melahirkan kelompok di bawah pimpinan Kiai Idham Chalid, yang mengkristal menjadi kelompok Cipete dan di sisi lain, kelompok di bawah pimpinan Kiai As'ad Syamsul Arifin Situbondo. Terbentuknya kedua kelompok manifes dalam tubuh NU, yang sedang berkonflik

${ }^{17}$ Slamet Efendi Yusuf., dkk., Op., Cit, h. 72

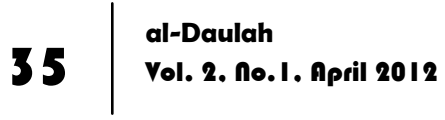


memperebutkan dukungan massa dalam membawa masa depan NU. Siapa saja diantara mereka yang menjadi pendukung kedua kelompok itu telah dikenali person-personnya, karena mereka kelompok elite NU yang terpandang dan terkenal. Kelompok Kiai Idham Chalid, terdiri atas Kiai Ali Yafie, H Aminuddin Aziz, H. Imam Sofwan, H. Nuddin Lubis, H Lukmanul Hakim, HM. Dahrif Nasution, HM. Amin Iskandar, HM. Baidhawi, HM Zahrie, Ny. Asmah Syachronie dan Chalid Mawardi. Kelompok kiai-kiai pesantren, dipimpin oleh Kiai As'ad Syamsul Arifin, disebut kelompok Kawatan. Kiai As'ad Syamsul Arifin memberikan tanggapan atas pernyataaan dan sikap tidak konsistennya Kiai Idham Chalid yang dianggap berubah-ubah dan tidak mempunyai arah yang jelas.

Sikap Kiai Idham Chalid yang demikian makin menjauhkan hubungan pribadinya dengan Kiai As'ad Syamsul Arifin, selaku wakil dari kelompok Kawatan, yang merasa dibikin kecewa atas sikapnya yang plin-plan. Meskipun demikian kelompok Kawatan berusaha mendatangi rumah Kiai Idham Khalid lagi untuk membahas penarikan kembali pernyataan pencabutan pengunduran diri tanpa dihadiri oleh Kiai As'ad Syamsul Arifin. Dalam pertemuan itu tidak menghasilkan sesuatu yang berarti bagi missi kelompok Kawatan meski didatangi para pengurus PB NU, yaitu Rais Aam Kiai Ali Maksum; Wakil Rais Aam, Anwar Musaddad; Rais Tsani, Kiai Masykur; Rais Tsalis, Kiai Syaifuddin Zuhri; Rais Rabi' H. Imran Rosyadi dan dari Katib Awal dan Katib Tsani, yaitu Kiai Abdurrahman Wahid dan HM Rodhi Shaleh ${ }^{18}$.

Tanda-tanda perseteruan antara Kiai Idham Chalid dengan Kiai As'ad Syamsul Arifin telah diketahui sejak tahun 1971, dimana kedua tokoh ini sudah tidak begitu mesra. Bahkan pada pelaksanaan muktamar NU ke 25 yang bertempat di Surabaya, pada waktu itu, Kiai As'ad Syamsul Arifin minta dengan hormat agar tidak mencalonkan diri lagi sebagai ketua umum PBNU.

18 Ibid, h. 85- 105

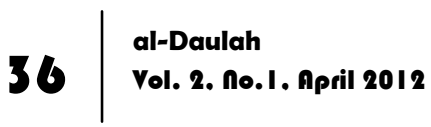


Permintaan yang sifatnya pribadi dari seorang kiai yang menjadi saksi pelaku sejarah berdirinya NU, dan ia menyerukan perlunya memulai tradisi regenerasi didalam tubuh NU. Kiai Idham Chalid menjabat pucuk pimpinan NU, telah berlangsung lama, harapan dari Kiai As'ad Syamsul Arifin agar ia dengan sukarela tidak lagi berambisi mencalonkan diri kembali.

Kiai Idham Chalid sejak berkenalan dengan Kiai Wahid Hasyim, tahun 1950, diangkat sebagai asisten pribadinya. Hubungan antara asisiten dengan tokoh pendiri NU, yang juga putra Kiai Hasyim Asy'ari, makin dekat dan berlanjut terus sampai ia diangkat pimpinan NU. Dari mula-mula berstatus sebagai asisten, lambat laun mendapat kepercayaan lebih besar dari Kiai Wahid Hasyim, dan karier politiknya di NU diawali tahun 1956, yang mendapatkan tugas memimpin NU dengan jabatan ketua Tanfidziyah NU. Karena itu, usulan Kiai As'ad Syamsul Arifin menjadi amat penting dalam proses alih kepemimpinan di tubuh NU, karena ia telah menjabat pimpinan NU berlangsung selama hampir 15 tahun. Namun pertemuan tersebut tidak membuahkan hasil, sebagaimana yang diperkirakan sebelumnya, meski hadir beberapa kiai dari pesantren-pesantren, seperti, Kiai Makhrus Ali dari pesantren Lirboyo Kediri, Para peserta muktamar tetap menghendaki Kiai Idham Chalid sebagai ketua umum tanfidziyah. Peserta muktamar memilihnya sebagai pimpinan NU didasarkan pada pesan Kiai Wahab Chasbullah dan Kiai Bisri Syansuri. Meski dengan berat hati Kiai As'ad Syamsul Arifin merelakan jabatan itu dan memberikan kesempatan sekali lagi untuk memimpin NU. Pada waktu itu, Kiai As'ad Syamsul Arifin bersikap pasif setelah menerima pesan dari kedua kiai tersebut dan tetap menghormati sebagai bagian dari tradisi pesantren. Kemungkinan besar para peserta muktamar memilih kembali Kiai Idham Chalid karena ada kabar mendapat dukungan sesepuh NU, yaitu Kiai Wahab Chasbullah.

Perseteruan antara kelompok Cipete dan Situbondo, terjadi tahun 1982, yang berasal dari ketidaksetujuan Kiai As'ad Syamsul

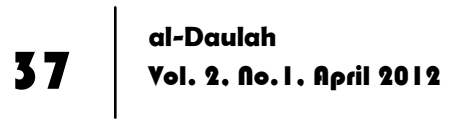


Arifin dalam pencalonan kembali Kiai Idham Chalid, pada muktamar tahun 1971. Indikasi perseteruan antara kedua figur muncul kembali dengan porsi yang lebih hebat lagi tatkala pelaksanaan muktamar yang ke 26 pada tahun 1979, berlangsung di Semarang. Kekecewaan Kiai As'ad Syamsul Arifin yang kedua kalinya ini adalah akibat sikap Kiai Idham Chalid yang mencalonkan kembali dirinya sebagai ketua umum PBNU. Sikap ini dianggap oleh Kiai As'ad Syamsul Arifin sebagai pengingkaran atas janjinya pada saat pelaksanaan muktamar, tahun 1971. Pada saat pengumuman hasil akhir penetapan Kiai Idham Chalid sebagai ketua PB NU, Kiai As'ad Syamsul Arifin meninggalkan ruangan muktamar sebagai bentuk dari rasa jengkel dan kekecewaan yang mendalam dari inkonsistensi pimpinan NU itu ${ }^{19}$. Muktamar di Semarang dijadikan sebagai momen yang kuat bagi kelompok Kiai Idham Chalid yang didominasi oleh kalangan muda NU yang berorientasi dalam partai politik. Dalam periode kepemimpinan Kiai Idham Chalid, hasil muktamar di Semarang ini, hampir terputus komunikasi antara kiai-kiai pesantren dengan Kiai Idham Chalid, selaku ketua PB NU. Karena style politiknya lebih berambisi mendidik kader-kader NU menjadi kader politik daripada pewaris tradisi keilmuan kiai, minimnya kader NU yang bergerak di bidang sosial agama, dan kurangnya perhatian NU sendiri terhadap pesantren.

Kebijakan Kiai Idham Chalid ini menimbulkan rasa kebencian atau paling tidak kekecewaan dari sebagian kiai-kiai di pesantren. Ia dianggap tidak memiliki kepekaan terhadap dunia pendidikan di pesantren. Dalam kepemimpinannya, orientasi program organisasi NU tidak menyentuh kebutuhan riil warga NU dan terabaikannya komunikasi dengan pesantren. Ketika ia terpilih sebagai ketua PBNU pada tahun 1971 terjadi perubahan politik, dimana keberadaan partai-partai politik dibawah kendali pemerintah Orde Baru. Ia lebih memperhatikan aspek politik 
dalam membawa organisasi NU daripada membangun tradisi keagamaan warga nahdiyin, para politisi NU tidak memikirkan bagaimana membangun pondok-pondok pesantren agar kualitasnya lebih maju.

Pada tahun 1971, jumlah partai politik sebanyak 10 buah disederhanakan menjadi 3 partai kontestan pemilu, PPP, PDI dan Golkar. Kebijakan ini merupakan momentum bagi Kiai Idham Chalid dalam menata politik warga NU, agar tetap bisa menyuarakan hak politiknya. Dengan alasan membangun kekuatan NU, maka strategi kepemimpinan Kiai Idham Chalid, tidak jauh berbeda dengan gaya kepemimpinan yang ia lakukan sebelumnya, yaitu terlibatnya politik warga NU. Ia tetap memimpin NU dengan memberikan perhatian lebih besar dalam politik NU daripada kegiatan-kegiatan non politik atau sosial keagamaan NU. Pengaruh Kiai Idham Chalid dalam membangun politik NU menyeret arah perjuangan NU dalam mainstream politik, dimana muncul kader-kader muda NU yang senang berkarier di bidang politik, di sisi lain kegiatan umat hampir sama sekali tidak tersentuh oleh kebijakan NU.

\section{Dampak Politik Khitah NU}

Dengan munculnya 2 kelompok di internal NU, yang masingmsing dipimpin oleh mereka yang memiliki latar belakang hampir sama, yaitu pernah mengenyam pendidikan di pesantren, maka timbul patronase dengan kiai-kiai di pesantren. Sistem patronase ini telah mempengaruhi perjalanan NU dikemudian hari. Kelompok pertama dipimpin oleh Kiai Idham Chalid, sekaligus sebagai ketua PB NU, yang menghendaki agar organisasi NU tetap menjaga komitmennya terlibat penuh, tanpa ragu-ragu dalam kegiatan partai politik dan menjadikan PPP sebagai kendaraan politik bagi warga NU. Sedangkan kelompok kedua, dipimpin oleh kalangan ulama pesantren yang terdiri atas Kiai Ahmad Siddiq dari Jember, Kiai Hamid dari Pasuruan, dan Kiai Ali Maksum dari Jogjakarta, yang menghendaki agar NU lebih baik 
kembali pada bentuk organisasi sosial keagamaan, yang konsentrasi pada kegiatan pendidikan dan dakwah.

Kedua kelompok ini berbeda pandangan dalam membawa NU dimasa depan, di satu sisi, terdapat kelompok yang menitikberatkan pada aspek politik sebagai bidang perjuangan NU dan di sisi lain, muncul kelompok yang menitikberatkan pada perjuangan dalam aspek sosial-keagamaan. Dari kepentingan yang berbeda ini, muncul gagasan baru yang dicetuskan oleh Kiai Yusuf Hasyim, yang ingin menjembatani antara kedua kubu yang saling berbeda pandangan itu. Ia berusaha untuk mencari titik temu, agar kedua kelompok tidak saling merasa dirugikan. Adapun konsep yang disodorkan merupakan bentuk kombinasi yang berupaya memadukan pandangan kedua kelompok yang saling berbeda kepentingan. Menurut Kiai Yusuf Hasyim, gagasan mengembalikan NU pada khittah 1926 tetap harus diwujudkan tanpa harus meninggalkan kegiatan politik sesuai dengan porsinya, sehingga potensi NU tidak melulu dicurahkan ke partai. Gagasan kembalinya NU ke khitah 1926 sebagai koreksi atas terabaikannya kegiatan-kegiatan sosial selama NU menjadi bagian dari komunitas politik. Menurut Kiai Yusuf Hasyim, bahwa pemikiran ke khitah NU 1926 bermaksud memperbaiki kinerja sosial NU. Dengan khitah tetap tidak diingkari hak-hak politik warga NU sebagai suatu kewajiban hidup berbangsa dan bernegara tetapi NU sendiri berkewajiban menjalankan fungsi sosial agamanya ${ }^{20}$.

Sebenarnya kelompok non khitah adalah kelompok yang sulit diidentifikasi person-personnya secara jelas. Berapa banyak orangorang yang tergabung dalam barisan menentang khitah dengan pengertian NU keluar PPP. Kelompok non khitah terdiri dari segelintir orang-orang yang sedang duduk di jabatan politis, fungsionaris PPP maupun menjabat anggota parlemen dari tingkat pusat sampai tingkat daerah. Jika setiap orang NU yang duduk 
dalam jabatan tersebut disebut kelompok penentang khittah berarti mereka sendiri tidaklah solid dan seragam dalam menghadapi barisan kelompok khittah. Atau barisan non khitah tidak semuanya menampakan jati dirinya sebagai penentang khitah dengan alasan tidak strategis bagi kepentingan dirinya sendiri. Mereka telah memahami seluk beluk kultur politik di NU, sehingga mereka lebih baik mengambil sikap diam karena bagaimanapun statusnya dalam menduduki jabatan politis itu tidak lepas dari pengaruh ulama-ulama pesantren. Peran ulamaulama pesantren melakukan mobilisasi massa NU untuk mencoblos PPP, telah memberikan kontribusi atas terpilihnya mereka menjadi anggota legislatif. Memang sebagian besar massa NU berada di barisan kelompok khittah. Rata-rata sebagian kelompok non khitah yang masih sering berkomunikasi dengan pihak kiai-kiai tetap menjaga posisi hubungan baiknya dengan para kiai/kelompok khitah, yang memimpin pesantren.

Identifikasi terhadap kelompok non khitah tingkat lokal agak sulit dibandingkan dengan di lapisan elit atas NU, sebagaimana dijelaskan tersebut di atas bahwa politisi lokal tidak mau ambil resiko dengan kiai-kiai pendukung khitah yang bertempat tinggal di pesantren. Dari sekian banyak pendukung non khitah, yang menjabat fungsionaris partai tingkat pusat dan menjadi anggota legislatif pusat, terdapat nama-nama yang menjadi pelopor gerakan menentang keputusan khitah, dalam pengertian khitah meninggalkan hak politiknya ke PPP. Mereka terdiri atas kiaipolitisi atau mubaligh-politisi, seperti, Kiai Idham Chalid, Kiai Syansuri Badawi, Kiai. Adlan Aly, H Khalid Mawardi, H Imam Sofyan dan $\mathrm{H}$ Muhammad Baidhawi ${ }^{21}$. Kelompok ini memperjuangkan hak politik warga NU di PPP, mereka menginginkan pengertian khitah tidak diarahkan meninggalkan PPP. Warga NU yang mendukung kelompok ini adalah rata-rata pendukung setia PPP yang terlibat dalam setiap even-even besar

${ }^{21}$ Hilmy Mochtar, Op., Cit, h., 127

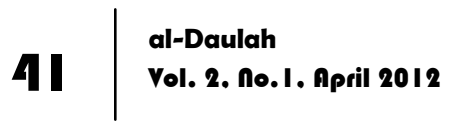


PPP. Dua tokoh kiai yang masuk kelompok non khitah, yaitu Kiai Adlan Aly dan Kiai Syansuri Badhawi adalah sosok kiai yang berpengaruh di kawasan Jawa Timur, mereka berdua bertempat tinggal di wilayah Tebuireng Jombang, selaku fungsionaris PPP22. Kedua tokoh ini memilih jalan yang berbeda dengan Kiai Yusuf Hasyim, padahal sebelum pelaksanaan muktamar NU Situbondo, mereka bertiga merupakan sosok yang disebut sebagai trio-leader PPP dari pesantren Tebuireng.

Perbedaan pandangan tentang kebijakan khitah, antara Kiai Yusuf Hasyim dengan Kiai Adlan Aly dan Kiai Syansuri Badhawi, menimbulkan beberapa kelompok di tingkat grass-root NU di Jombang23. Sebelum pelaksanaan muktamar NU di Situbondo, posisi Kiai Yusuf Hasyim adalah tokoh nasional di PPP, yang mempunyai pengaruh besar di wilayah Jawa Timur. Ia adalah salah satu kiai yang pernah menentang sikap Kiai Musta'in masuk Golkar dan berpandangan lain, setidaknya dengan dua koleganya terhadap PPP pasca muktamar. Di satu sisi, pasca muktamar NU Situbondo, Kiai Yusuf Hasyim bersikap lunak dalam memahami langkah-langkah pesantren Darul Ulum, yang sejak tahun 1977 telah menyeberang ke Golkar, tetapi disisi lain, ia justru berlawanan arah dengan dua sosok kiai tersebut dalam memahami keputusan pesantren Darul Ulum masuk Golkar. Sikap terjang politik yang berbeda diantara mereka ketiga telah menimbulkan dinamika politik lokal di tingkat Jombang. Warga pondok pesantren Tebuireng tetap komitmen memegang hasil keputusan NU kembali ke khitah dibawah kepemimpinan Kiai Yusuf Hasyim. Sedangkan Kiai Adlan Aly, selaku pimpinan pesantren Walisongo dan Kiai Syansuri Badhawi, sebagai rektor IKAHA tetap berada dalam barisan $\mathrm{PPP}^{24}$. Sebenarnya terjadinya perbedaan di tingkat warga NU mengenai pemahaman khitah bersumber dari perbedaan pendapat yang terjadi di tingkat elite

\footnotetext{
${ }^{22}$ Sukamto, Kepemimpinan Kiai Dalam Pesantren, LP3ES, Jakarta, 1999, h. 31 I

${ }^{23}$ Wawancara dengan Gus Taufiqurrahman, 15 Mei 2005

24 ibid
} 
organisasi NU, dimana sosok Kiai Idham Chalid difigurkan sebagai pimpinan kelompok non khittah yang berhadapan dengan kelompok khitah, yang diwacanakan sebagai kelompok Kiai As'ad Syamsul Arifin. Kedua figur kiai ini menjadi simbol masingmasing kelompok warga NU, yang saling berseberangan dalam membawa visi misi gerbong NU. Mereka berdua memiliki perbedaan dalam memahami fungsi organisasi NU dalam konteks sosial dan politik dan saling mengklaim sebagai pewaris NU dan bertanggung jawab membawa masa depan NU yang lebih baik. Kedua pihak juga berwenang dalam mengambil kebijakankebijakan yang strategis dalam memajukan organisasi NU.

\section{Penutup}

Diselenggarakannya muktamar NU di Situbondo dengan tujuan mengevaluasi sejauhmana keuntungan dan kerugian politis yang diperoleh NU selama bergabung dalam PPP. Tetapui evaluasi ini sebelumnya dapat ditebak hasilnya, yaitu kerugian yang diderita NU lebih besar daripada keuntungan yang diperoleh, apalagi pertengahan 80-an NU dirundung konflik dengan pimpinan PPP. Di sisi lain, keputusan muktamar sebagai titik puncak dari sikap tidak harmonisnya antara kelompokkelompok internal NU sendiri dalam memahami posisinya dalam PPP. Kepentingan yang berbeda antara unsur-unsur partai yang tergabung dalam PPP menjadi tidak seimbang dan dirasakan oleh sebagian besar ulama pesantren merugikan warga NU sendiri. Perbedaan yang demikian menimbulkan disharmonisasi dalam internal NU, yaitu antara orang-orang NU yang berpredikat politisi berhadapan dengan kiai-kiai di pesantren. Sementara itu, politisi NU di PPP tidak bisa berbuat banyak dalam menghadapi perseteruan internal PPP yang dianggap merugikan warga NU. Para kiai selalu menyampaikan kegusarannya pada politisi NU, bahwa masak NU yang mempunyai massa pendukung lebih besar dari unsur partai lainnya mengikuti kemauan unsur-unsur partai yang memiliki massa pemilih minoritas. Gejala polarisasi warga

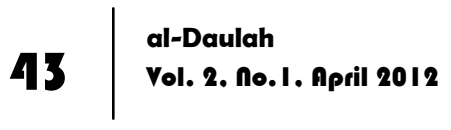


NU makin tak terbendung setelah implementasi khitah memasuki wilayah cabang-cabang NU di seluruh daerah di Indonesia. Kebijakan khitah NU menimbulkan perpecahan antara warga NU yang masih setia dengan PPP dan warga NU yang menghendaki khitah. Masing-masing kelompok dipimpin oleh kiai yang berbeda dan mengklaim memperoleh dukungan massa dari warga NU, dengan klaimnya itu telah memperbesar jurang perbedaan di internal NU. Di tingkat kepengurusan NU, lompok ini mendapat dukungan dari elite NU yang berbeda, yang justru menambah friksi NU dalam konteks kepentingan yang selalu berlainan.

\section{Daftar Pustaka}

Mudatsir, Arif, Dari Situbondo Menuju NU Baru, dalam Prisma, Edisi Ekstra, 1984.

Anam, Choirul, Pertumbuhan dan Perkembangan Nahdhatul Ulama, Solo, Jatayu, 1985.

M. Sitompul, Einar, NU, Asas Tunggal Pancasila dan Komitmen Kebangsaan; Refleksi Kiprah NU Pasca Kitah 26., dalam Gus Durn

NU dan Masyarakat Sipil (Ellyasa KH. Darwis, editor), Yogjarakat, LkiS, 1994.

Turmudi, Endang, Perselingkuhan Kiai Dan Kekuasaan, Yogjakarta, LkiS, 2004.

Feillard, Andree, Nahdhatul Ulama dan Negara; Fleksibelitas,

Legitimasi dan Pembaharuan, dalam Gus Dur, NU dan Masyarakat Sipil, (Ellyasa KH Darwis, editor), LkiS, Yogjakarta, 1994.

Mochtar, Hilmy, Dinamika Nahdhatul Ulama; Suatu Studi Tentang

Elite Kekuatan Politik Islam di Jombang Jawa Timur, Tesis S-2 Universitas Gajah Mada, 1987.

Marijan, Kacung, Quo Vadis NU Setelah Kembali ke Khitah 1926, Surabaya, Penerbit Erlangga, 1992.

Lidlle, William, Indonesia in 1987; The New Order at the height of its Power, dalam Political Science, The Ohio State University, 1988. 
Sujuthi, Mahmud, Politik Tarekat Qadiriyah Wa Naqsabandiyah Jombang; Hubungan Agama, Negara dan Masyarakat, Yogjakarta, Galang Press, 2001.

Hikam, Muhammad AS, Khitah dan Penguatan Civil Society di Indonesia; Sebuah Kajian Historis dan Struktural atas NU sejak tahun 1984, dalam Gus Dur, NU dan Masyarakat Sipil, Yogjakarta, LkiS, 1994.

Rafiuddin, Riaty, Pengaruh Kiai NU Terhadap Kecenderungan Memilih Di Kalangan Santri Dalam Pemilu 1987; Studi Kasus 4 Pondok Pesantren di Jombang Jawa Timur, Skripsi Fakultas Ilmu Sosial dan Ilmu Politik Universitas Indonesia, Jakarta, 1991.

Efendi Yusuf, Slamet, dkk., Dinamika Kaum Santri; Menelusuri Jejak dan Pergolakan Internal NU, Jakarta, Grafiti Press, 1983.

Sukamto, Kepemimpinan Kiai Dalam Pesantren; Pudarnya Kekuasaan Kiai, Jakarta, LP3ES, 1999.

A. Hasan, Syamsul, (editor) Kharisma Kiai As'ad di Mata Umat, Yogjakarta, LkiS., 2003.

Radi, Umaidi, Strategi PPP; Suatu Studi Tentang Kekuatan Politik Tingkat Nasional, Jakarta, Integritas Press, 1984. 